\title{
Antiviral biflavonoids from Radix Wikstroemiae (Liaogewanggen)
}

\author{
Weihuan Huang ${ }^{1}$, Xiaoli Zhang ${ }^{2,3}$, Yifei Wang ${ }^{4}$, Wencai Ye2,3, Vincent EC Ooi ${ }^{1}$, Hau Yin Chung ${ }^{1}$ and Yaolan Li*2,3
}

\begin{abstract}
Background: Radix Wikstroemiae is a common Chinese herbal medicine. The ethyl acetate fraction of the ethanolic extract of $W$. indica possesses potent in vitro antiviral activity against respiratory syncytial virus (RSV). This study aims to identify the antiviral components of the active fraction.

Methods: The active fraction of the Radix Wikstroemiae extract was isolated with chromatographic methods such as silica gel, Sephadex LH-20 and semi-preparative high performance liquid chromatography (HPLC) columns. The structures of the isolated compounds were determined based on spectroscopic analyses. The in vitro antiviral activity of the compounds against RSV was tested with the cytopathic effect (CPE) reduction assay and the 3-(4,5dimethylthiazol-2-yl)-2,5-diphenyltetrazolium bromide (MTT) method.

Results: Four biflavonoids, namely neochamaejasmin B, genkwanol B, genkwanol C and stelleranol, were isolated and characterized. Genkwanol B, genkwanol C and stelleranol, which are stereo isomers of spirobiflavonoids, showed potent anti-RSV activity whereas neochamaejasmin B did not.

Conclusion: Neochamaejasmin B, genkwanol B, genkwanol C and stelleranol were isolated from Radix Wikstroemiae and the complete absolute configurations of five chiral carbons in stelleranol were substantiated for the first time. Furthermore, the anti-RSV activity of genkwanol B, genkwanol C and stelleranol was reported for the first time.
\end{abstract}

\section{Background}

The root of Wikstroemia indica (Linn.) C. A. Mey. (Thymelaeaceae) (Radix Wikstroemiae, Liaogewanggen) is a Chinese herbal medicine used to treat various inflammatory conditions [1]. W. indica tablet, an over-thecounter product made from the aqueous extract of Radix Wikstroemiae, is commercially available in China for the treatment of bronchitis, pneumonia, tonsillitis, parotitis and mastitis according to the Pharmacopoeia of China [2]. Moreover, W. indica have antifungal, anti-inflammatory, anti-cancer, antiviral and antimalarial effects [3-6]. Bioactive components of W. indica include (+)-nortrachelogenin, bis-5,5-nortrachelogenin, tricin, genkwanol A, kaempferol-3-O-beta- $D$-glucopyranoside, wikstrol A, wikstrol B, daphnodorin B, sikokianin B, sikokianin C, indicanone, lirioresinol $B$ and daphnoretin [3-8]. In our previous study, the ethyl acetate fraction of the ethanolic extract of Radix Wikstroemiae possessed in vitro antiviral

\footnotetext{
* Correspondence: tliyl@jnu.edu.cn

2 Institute of Traditional Chinese Medicine and Natural Products, Jinan University, Guangzhou, 510632, China

Full list of author information is available at the end of the article
}

activity against RSV with $\mathrm{IC}_{50}$ value of $<3.9 \mu \mathrm{g} / \mathrm{ml}$ and selective index (SI) of $>64.1$. Besides, daphnoretin (a dicoumarin compound) is one of the active components in the fraction, which mainly exerts its antiviral effects on the later phase of the viral replication cycle [9]. This article reports the isolation, structural characterization and in vitro antiviral tests of four biflavonoids, namely, (I) neochamaejasmin B, (II) genkwanol B, (III) genkwanol C and (IV) stelleranol from the ethyl acetate fraction of the ethanolic extract of Radix Wikstroemiae.

\section{Methods}

Plant material

Radix Wikstroemiae was purchased from a Chinese medicine pharmacy in Guangzhou, China. The authentication process was carried out by Zhengqiu Mai (Chinese Medicinal Material Company, Guangzhou, China) according to standard protocols [2]. A voucher specimen was deposited in the Institute of Traditional Chinese Medicine and Natural Products, College of Pharmacy, 
Jinan University (Guangzhou, China) with an accession number of 06111205.

\section{General experimental procedures}

Optical rotations were determined on a Jasco P-1020 digital polarimeter (JASCO Corporation, Japan). The spectra of electrospray ionization-mass spectrometry (ESIMS) were recorded on a Finnigan LCQ Advantage Max ion trap mass spectrometer (Thermo Finnigan, USA). The spectra of high resolution-electrospray ionizationmass spectrometry (HR-ESI-MS) were acquired with a Micromass Q-TOF mass spectrometer (Waters Corporation, USA). The spectra of nuclear magnetic resonance spectrometry (NMR) including proton magnetic resonance spectrometry $\left({ }^{1} \mathrm{H}-\mathrm{NMR}\right)$ and carbon magnetic resonance spectrometry $\left({ }^{13} \mathrm{C}-\mathrm{NMR}\right)$ were obtained on a Bruker spectrometer (Bruker Corporation, Switzerland) operating at $500 \mathrm{MHz}$ for ${ }^{1} \mathrm{H}-\mathrm{MNR}$ and $125 \mathrm{MHz}$ for ${ }^{13} \mathrm{C}$ NMR respectively. The isolation process was conducted on silica gel (200-300 meshes, Qingdao Marine Chemical, China), Sephadex LH-20 (25-100 $\mu \mathrm{m}$, Fluka, Switzerland) and semi-preparative HPLC. Semi-preparative HPLC was performed on an Eclipse XDB- $\mathrm{C}_{18}$ column (9.4 mm ID $\times$ $25 \mathrm{~cm}$ ) (Agilent Technologies, USA). Thin layer chromatography (TLC) was carried out on silica gel $\mathrm{GF}_{254}$ plates $(0.2 \mathrm{~mm}$ thickness, $10 \times 20 \mathrm{~cm}$, Qingdao Marine Chemical, China) with $\mathrm{FeCl}_{3}-\mathrm{EtOH}$ reagent and ultraviolet (UV) illumination as chromogenic methods.

\section{Extraction and isolation}

The dried and cut Radix Wikstroemiae (10.0 kg) was soaked in $95 \%$ ethanol at room temperature for three times (15 days each time). The ethanol solutions were then combined and concentrated in vacuo to yield a dark brown crude extract $(1.0 \mathrm{~kg})$. The ethanol extract was suspended in distilled water and partitioned with petroleum ether, ethyl acetate and $n$-butanol successively. After evaporation under reduced pressure, the petroleum ether fraction $(5.0 \mathrm{~g})$, ethyl acetate fraction $(580.0 \mathrm{~g})$ and butanol fraction $(400.0 \mathrm{~g})$ were obtained respectively.

The ethyl acetate fraction $(550.0 \mathrm{~g})$ was chromatographed on a silica gel column eluted with a solvent system of petroleum ether/ethyl acetate in gradient to obtain 28 subfractions based on the TLC analysis. The subfractions $\mathrm{Fr}-12$ and $\mathrm{Fr}-23$, which yielded positive reaction with $\mathrm{FeCl}_{3}-\mathrm{EtOH}$ reagent, were further isolated.

Fr-12 (12.6 g) was isolated with repeated silica gel columns eluted with gradient solvent systems of chloroform/acetone and chloroform/methanol, respectively, followed by Sephadex LH-20 column eluted with chloroform/methanol (3/7) to yield compound I (20.0 mg).

Fr-23 (12.6 g) was subjected to repeated silica gel columns eluted with gradient solvent system of chloroform/ methanol, followed by semi-preparative HPLC on an
Eclipse XDB- $\mathrm{C}_{18}$ column (Agilent Technologies, USA) with a gradient solvent system of $0.1 \%$ TFA (A) and methanol (B) to yield compounds II $(40.7 \mathrm{mg})$, III $(60.3 \mathrm{mg})$ and IV (20.7 mg).

\section{Identification}

Compound I (neochamaejasmin B), an amorphous brown powder, was positive to $\mathrm{FeCl}_{3}-\mathrm{EtOH}$ reagent. $[\alpha]_{\mathrm{D}}=200^{\circ}$ (c 0.1, MeOH). ESI-MS: $m / z 541[\mathrm{M}-\mathrm{H}]-{ }^{1} \mathrm{H}-\mathrm{NMR}(500$ $\left.\mathrm{MHz}, \mathrm{CD}_{3} \mathrm{OD}\right) \delta: 7.17\left(2 \mathrm{H}, \mathrm{d}, J=8.4 \mathrm{~Hz}, \mathrm{H}-2{ }^{\prime \prime}, \mathrm{H}-6{ }^{\prime \prime}\right)$, $6.94\left(2 \mathrm{H}, \mathrm{d}, J=8.4 \mathrm{~Hz}, \mathrm{H}-2^{\prime}, \mathrm{H}-6^{\prime}\right), 6.81(2 \mathrm{H}, \mathrm{d}, J=8.4 \mathrm{~Hz}$, H-3'", H-5"'), 6.67 (2H, d, J = 8.4 Hz, H-3', H-5'), $6.00(1 \mathrm{H}$, d, $J=1.8 \mathrm{~Hz}, \mathrm{H}-8 "), 5.89(1 \mathrm{H}, \mathrm{d}, J=1.8 \mathrm{~Hz}, \mathrm{H}-8), 5.80(1 \mathrm{H}$, $\mathrm{d}, J=1.8 \mathrm{~Hz}, \mathrm{H}-6 "), 5.78(1 \mathrm{H}, \mathrm{d}, J=1.8 \mathrm{~Hz}, \mathrm{H}-6), 5.57(1 \mathrm{H}$, $\mathrm{d}, J=4.6 \mathrm{~Hz}, \mathrm{H}-2), 5.16(1 \mathrm{H}, \mathrm{d}, J=8.8 \mathrm{~Hz}, \mathrm{H}-2)), 3.29(1 \mathrm{H}$, $\mathrm{dd} J=3.2,8.8 \mathrm{~Hz}, \mathrm{H}-3 "), 3.16(1 \mathrm{H}$, brs, $\mathrm{H}-3) .{ }^{13} \mathrm{C}-\mathrm{NMR}$ (125 MHz, CD $\mathrm{OD}$ ) $\delta: 198.6$ (C-4"), 196.3 (C-4), 168.3 (C7"), 168.1 (C-7), 165.1 (C-8"a), 165.4 (C-5"), 165.2 (C-5), 163.4 (C-8a), 159.0 (C-4"'), 158.6 (C-4'), 130.3 (C-2"', 6"'), 129.1 (C-1"'), 128.8 (C-1'), 128.5 (C-2', 6'), 116.4 (C-3"', 5'), 116.2 (C- 3', 5'), 105.1 (C-4"a) ,103.9 (C-4a), 97.3 (C6"), 97.1 (C-6), 96.4 (C-8"), 96.0 (C-8), 83.3 (C-2"), 81.5 (C-2), 50.8 (C-3"), 49.7 (C-3).

Compound II (genkwanol B), a light yellow powder, was positive to $\mathrm{FeCl}_{3}$-EtOH reagent. $[\alpha]_{\mathrm{D}}=-160^{\circ}$ (c 0.1 , MeOH). HR-ESI-MS $m / z: 557.10805$ [M-H] - ${ }^{1} \mathrm{H}-\mathrm{NMR}$ $\left(500 \mathrm{MHz}, \mathrm{DMSO}-d_{6}\right) \delta: 7.09(2 \mathrm{H}, \mathrm{d}, J=8.5 \mathrm{~Hz}, \mathrm{H}-2 \mathrm{\prime}, \mathrm{H}-$ 6"'), $6.73(2 \mathrm{H}, \mathrm{d}, J=8.5 \mathrm{~Hz}, \mathrm{H}-3$ '", H-5"'), $6.58(2 \mathrm{H}, \mathrm{d}, J=$ $\left.8.5 \mathrm{~Hz}, \mathrm{H}-2^{\prime}, \mathrm{H}-6^{\prime}\right), 6.51\left(2 \mathrm{H}, \mathrm{d}, J=8.5 \mathrm{~Hz}, \mathrm{H}-3^{\prime}, \mathrm{H}-5^{\prime}\right)$, $6.11(1 \mathrm{H}, \mathrm{d}, J=2.0 \mathrm{~Hz}, \mathrm{H}-8 "), 6.04(1 \mathrm{H}, \mathrm{d}, J=2.0 \mathrm{~Hz}, \mathrm{H}-$ 6"), $5.71(1 \mathrm{H}, \mathrm{s}, \mathrm{H}-6), 4.56(1 \mathrm{H}, \mathrm{d}, J=8.2 \mathrm{~Hz}, \mathrm{H}-2), 3.55$ $(1 \mathrm{H}, \mathrm{m}, \mathrm{H}-3), 2.59(1 \mathrm{H}, \mathrm{dd}, J=8.9,16.7 \mathrm{~Hz}, \mathrm{H}-4), 2.05$ $(1 \mathrm{H}, \mathrm{dd}, J=5.0,16.7 \mathrm{~Hz}, \mathrm{H}-4) .{ }^{13} \mathrm{C}-\mathrm{NMR}(125 \mathrm{MHz}$, DMSO- $\left.d_{6}\right) \delta$ : $190.4(\mathrm{C}-4 "), 186.3(\mathrm{C}-5), 168.6$ (C-7), 167.7 (C-7"), 163.3 (C-5"), 160.1 (C-8"a), 158.1 (C-4"'), 157.9(C8a), 156.7 (C-4'), 129.8 (C-2"', 6"'), 127.9 (C-1'), 127.3 (C2', 6'), 122.0 (C-1"'), 114.6 (C-3"', 5"'), 114.4 (C-3', 5'), 109.2 (C-4a) ,100.4 (C-6), 99.8 (C-4"a), 97.0 (C-6"), 96.1 (C-8"), 89.9 (C-2"), 85.0 (C-8), 82.0 (C-2), 79.8 (C-3"), 66.4 (C-3), 27.0 (C-4).

Compound III (genkwanol C), a light yellow powder, was positive to $\mathrm{FeCl}_{3}-\mathrm{EtOH}$ reagent. $[\alpha]_{\mathrm{D}}=+15^{\circ}$ (c 0.1, $\mathrm{MeOH})$. HR-ESI-MS $m / z: 557.10863[\mathrm{M}-\mathrm{H}]={ }^{1} \mathrm{H}-\mathrm{NMR}$ $\left(500 \mathrm{MHz}, \mathrm{DMSO}-d_{6}\right) \delta: 7.07(2 \mathrm{H}, \mathrm{d}, J=8.5 \mathrm{~Hz}, \mathrm{H}-2 \mathrm{\prime}, \mathrm{H}-$ $6^{\prime \prime \prime)}, 6.96\left(2 \mathrm{H}, \mathrm{d}, J=8.5 \mathrm{~Hz}, \mathrm{H}-2^{\prime}, \mathrm{H}-6^{\prime}\right), 6.74(2 \mathrm{H}, \mathrm{d}, J=8.5$ Hz, H-3"', H-5"'), 6.51 (2H, d, $J=8.5$ Hz, H-3', H-5'), 6.00 $(1 \mathrm{H}, \mathrm{d}, J=2.0 \mathrm{~Hz}, \mathrm{H}-8 "), 5.93(1 \mathrm{H}, \mathrm{d}, J=2.0 \mathrm{~Hz}, \mathrm{H}-6 ")$, $5.72(1 \mathrm{H}, \mathrm{s}, \mathrm{H}-6), 4.61(1 \mathrm{H}, \mathrm{d}, J=6.5 \mathrm{~Hz}, \mathrm{H}-2), 3.77(1 \mathrm{H}$, $\mathrm{m}, \mathrm{H}-3), 3.16(1 \mathrm{H}, \mathrm{d}, J=6.5 \mathrm{~Hz}, \mathrm{H}-4), 2.21(1 \mathrm{H}, \mathrm{d}, J=4.0$ $\mathrm{Hz}, \mathrm{H}-4) .{ }^{13} \mathrm{C}-\mathrm{NMR}\left(125 \mathrm{MHz}, \mathrm{DMSO}-d_{6}\right) \delta: 190.3$ (C4"), 186.3 (C-5), 168.5 (C-7), 167.3 (C-7"), 162.6 (C-5"), 160.2 (C-8"a), 158.1 (C-8a), 157.3 (C-4"'), 156.7 (C-4'), 129.6 (C-2'", 6"'), 127.8 (C-1'), 127.4 (C-2', 6'), 121.9 (C- 


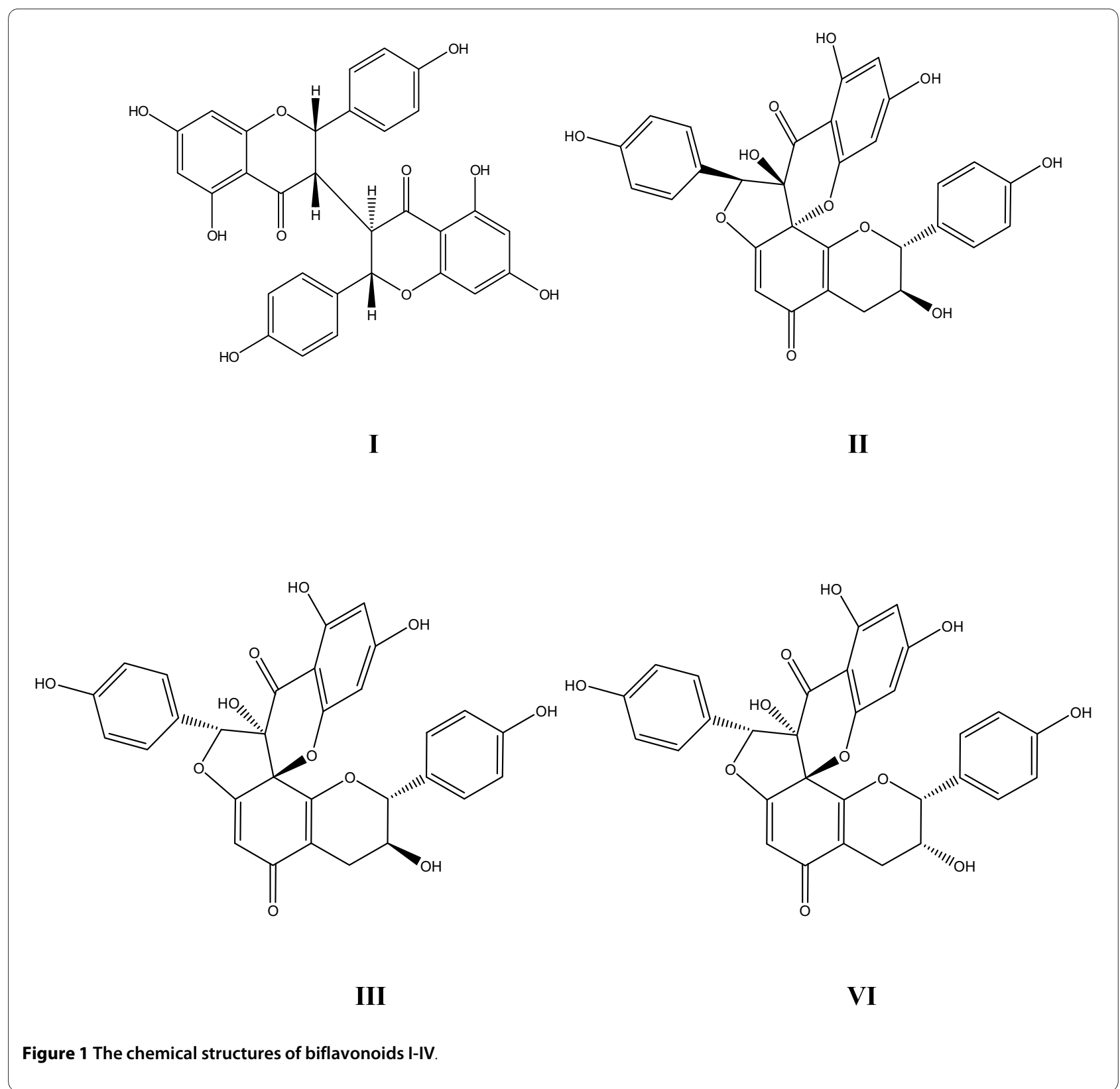

1"'), 114.6 (C-3"', 5"'), 114.5 (C-3', 5'), 109.5 (C-4a) ,100.48 (C-6), 99.2 (C-4"a), 97.8 (C-6"), 95.7 (C-8"), 90.4 (C-2"), 84.6 (C-8), 81.8 (C-2), 79.9(C-3"), 65.0(C-3), 25.5 (C-4).

Compound IV (stelleranol), a light yellow powder, was positive to $\mathrm{FeCl}_{3}$-EtOH reagent. $[\alpha]_{\mathrm{D}}=-102^{\circ}$ (c 0.1, $\mathrm{MeOH})$. HR-ESI-MS $m / z: 557.10913$ [M-H] - CD (c $\left.6.25 \times 10^{-5}, \mathrm{MeOH}\right) \Delta \varepsilon(\mathrm{nm}): 0$ (394), -6.8 (342), 0 (327), +31.8 (305), 0 (279), -18.6 (259), -7.5 (242), - 21.2 (219), 0 (206). ${ }^{1} \mathrm{H}-\mathrm{NMR}\left(500 \mathrm{MHz}\right.$, acetone- $\left.d_{6}\right) \delta: 7.22(2 \mathrm{H}, \mathrm{d}, J=$ 8.5 Hz, H-2"', H-6"'), 6.83 (2H, d, J = 8.5 Hz, H-3"', H-5"'), $6.71\left(2 \mathrm{H}, \mathrm{d}, J=8.5 \mathrm{~Hz}, \mathrm{H}-2{ }^{\prime}, \mathrm{H}-6{ }^{\prime}\right), 6.62(2 \mathrm{H}, \mathrm{d}, J=8.5 \mathrm{~Hz}$, H-3', H-5'), $6.16\left(1 \mathrm{H}, \mathrm{d}, J=2.0 \mathrm{~Hz}, \mathrm{H}-8^{\prime \prime}\right), 6.14(1 \mathrm{H}, \mathrm{d}, J=$ $2.0 \mathrm{~Hz}, \mathrm{H}-6 "), 6.09$ (1H, s, H-2"), 5.68 (1H, s, H-6), 4.96 $(1 \mathrm{H}, \mathrm{s}, \mathrm{H}-2), 4.18$ (1H, brs, H-3), $2.65(1 \mathrm{H}, \mathrm{d}, J=17.5 \mathrm{~Hz}$,
$\mathrm{H}-4), 2.49$ (1H, dd, $J=3.8,17.3 \mathrm{~Hz}, \mathrm{H}-4) .{ }^{13} \mathrm{C}-\mathrm{NMR}(125$ $\mathrm{MHz}$, acetone- $\left.d_{6}\right) \delta: 193.1$ (C-4"), 188.7 (C-5), 170.4 (C7), 169.6 (C-7"), 166.1 (C-8"a), 163.1 (C-5"), 160.3 (C-8a), 159.9 (C-4"'), 158.6 (C-4'), 131.7 (C-2"', 6"'), 130.4 (C-1'), 129.2 (C-2', 6'), 124.7 (C-1"'), 116.7 (C-3"', 5"'), 116.5 (C-3', 5'), 111.1 (C-4a) ,102.9 (C-6), 102.0 (C-4"a), 99.0 (C-6"), 98.4 (C-8"), 92.2 (C-2"), 87.5 (C-8), 82.3 (C-2), 82.1 (C-3"), 66.5 (C-3), $28.6(\mathrm{C}-4)$.

\section{Cell and virus}

Human larynx epidermoid carcinoma cell line (HEp-2, CCL-23) and RSV (long strain, VR-26) were purchased from the American Type Culture Collection (ATCC, USA). The cells were grown in Eagle's minimum essential 


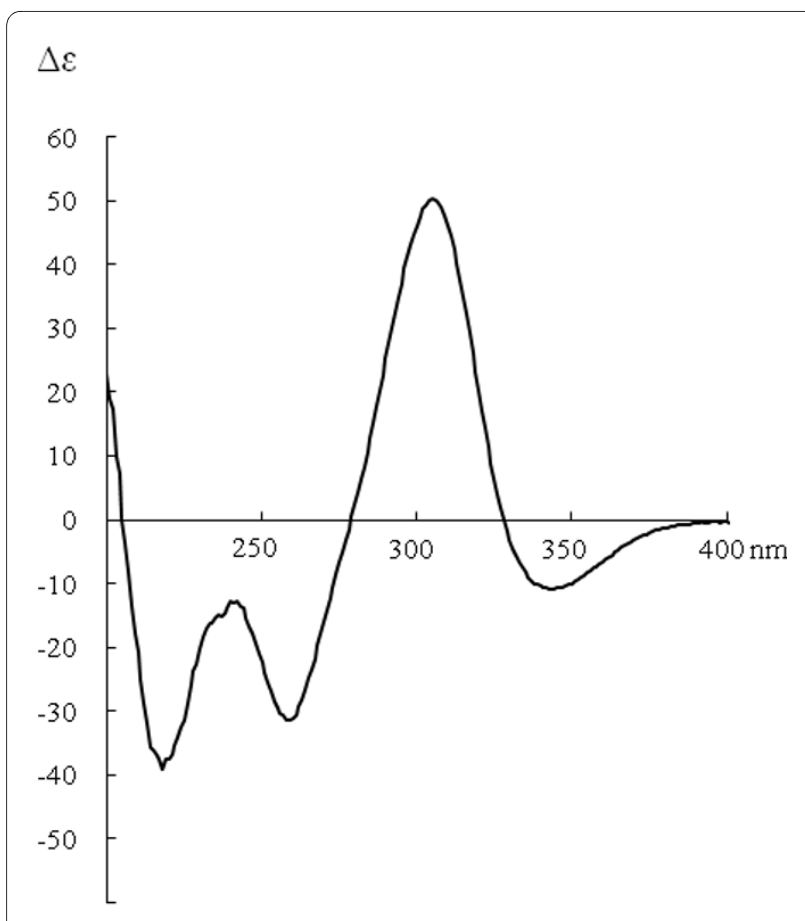

Figure 2 The CD spectra of biflavonoid IV in $\mathrm{MeOH}$.

medium (EMEM) (Gibco, USA) supplemented with $10 \%$ fetal bovine serum (FBS) (Gibco, USA), $25 \mu \mathrm{g} / \mathrm{ml}$ gentamicin (Sigma, USA) and $200 \mathrm{mM}$ L-glutamine (Sigma, USA) (growth medium). Virus-infected cells were maintained in EMEM with $1 \% \mathrm{FBS}, 25 \mu \mathrm{g} / \mathrm{ml}$ gentamicin and $200 \mathrm{mM}$ L-glutamine (maintenance medium). All the cells were cultured at $37^{\circ} \mathrm{C}$ in a humidified atmosphere supplied with $5 \% \mathrm{CO}_{2}$. Virus titers were determined by the $50 \%$ tissue culture infective dose $\left(\mathrm{TCID}_{50}\right)$ method.

\section{Cytotoxicity assay}

Cell viability was tested by the 3-(4,5-dimethylthiazol-2yl)-2,5-diphenyl tetrazolium bromide (MTT) method as described in previous study [10]. Briefly, $100 \mu \mathrm{l}$ of twofold diluted samples were added to a 96-well plate containing confluent cell monolayer in triplicates while the dilution medium without the sample was the control. After 72 hours of incubation, $12 \mu \mathrm{l}$ of the MTT solution ( $5 \mathrm{mg} / \mathrm{ml}$ in phosphate buffered saline) was added to each well. The trays were further incubated for four hours for the formation of blue formazan. After the supernatant was removed, the blue formazan was solubilized in $100 \mu \mathrm{l}$ DMSO and the optical density (OD) was measured at 570 $\mathrm{nm}$ with a microplate reader.

\section{Antiviral assay}

CPE reduction assay was adopted for screening the in vitro antiviral activity as described in the previous study [10]. Briefly, $0.1 \mathrm{ml}$ of $100 \mathrm{TCID}_{50}$ virus suspension and serial two-fold dilutions of the tested samples were added simultaneously to confluent cell monolayers in a 96-well plate. Virus suspension and maintenance medium without samples were added as the virus control and cell control, respectively. The plates were incubated at $37^{\circ} \mathrm{C}$ in a humidified $\mathrm{CO}_{2}$ atmosphere for 3-5 days. The virusinduced CPE was scored against the virus control under a light microscope. Ribavirin (Sigma, USA) was used as positive control in this experiment.

\section{Results}

\section{Chemical structures of the isolated compounds}

Compound IV was isolated as a light yellow powder. Positive $\mathrm{FeCl}_{3}$ reaction showed the presence of phenolic hydroxyl groups. The molecular formula of compound IV was determined to be $\mathrm{C}_{30} \mathrm{H}_{22} \mathrm{O}_{11}$ by HR-ESI-MS $(\mathrm{m} / z$ 557.10931 [M-H] -, calcd. for $\mathrm{C}_{30} \mathrm{H}_{21} \mathrm{O}_{11} m / z$ 557.10893). Proton and carbon signals were assigned by a combination of $1 \mathrm{D}$ - and $2 \mathrm{D}-\mathrm{NMR}$ spectra. The ${ }^{1} \mathrm{H}-\mathrm{NMR}$ spectrum of compound IV showed signals assignable to a pair of 1,4-disubstituted aromatic rings [ $\delta 7.22(2 \mathrm{H}, \mathrm{d}, J=8.5$ $\mathrm{Hz}), 6.71(2 \mathrm{H}, \mathrm{d}, J=8.5 \mathrm{~Hz}), 6.83(2 \mathrm{H}, \mathrm{d}, J=8.5 \mathrm{~Hz})$, and $6.62(2 \mathrm{H}, \mathrm{d}, J=8.5 \mathrm{~Hz})]$, one $1,2,4,6$-tetra substituted aromatic ring $[\delta 6.16(1 \mathrm{H}, \mathrm{d}, J=2.0 \mathrm{~Hz})$, and $6.14(1 \mathrm{H}, \mathrm{d}, J=$ $2.0 \mathrm{~Hz})]$ and one 3-hydroxy-2,5,6-trisubstituented dihydropyran $[\delta 4.96(1 \mathrm{H}, \mathrm{s}), 4.18(1 \mathrm{H}, \mathrm{brs}), 2.65(1 \mathrm{H}, \mathrm{d}, J=$ $17.5 \mathrm{~Hz}), 2.49(1 \mathrm{H}, \mathrm{dd}, J=3.8,17.3 \mathrm{~Hz})]$. Moreover, two

Table 1: In vitro anti-RSV activity of compounds I-IV $(n=3)$

\begin{tabular}{llll}
\hline Compound & $\mathbf{C C}_{\mathbf{5 0}}(\boldsymbol{\mu M}) \mathbf{a}$ & IC $_{\mathbf{5 0}}(\boldsymbol{\mu M}) \mathbf{b}$ & SI \\
\hline I & $29.9(3.2)$ & - & - \\
II & $106.1(5.9)$ & $9.6(0.7)$ & 21.9 \\
III & $145.3(3.1)$ & $6.6(1.1)$ & 11.0 \\
IV & $161.5(5.7)$ & $10.2(0.8)$ & 15.8 \\
Ribavirin & $256.1(3.2)$ & $11.9(0.2)$ & 21.6 \\
\hline
\end{tabular}

${ }^{a} \mathrm{CC}_{50}$ is the concentration of sample with half maximal inhibition on the growth and survival of HEp-2 cells; data are expressed as mean (SD).

${ }^{\mathrm{b}} \mathrm{IC} \mathrm{C}_{50}$ is the concentration that reduced $50 \%$ of CPE in respect to virus control; data are expressed as mean (SD).

-: The sample did not show anti-RSV effect at its NMCC. 
singlet signals were observed at $\delta 6.09(1 \mathrm{H}, \mathrm{s})$ and 5.68 $(1 \mathrm{H}, \mathrm{s})$. In the ${ }^{13} \mathrm{C}$-NMR spectrum of compound IV, two carbonyl carbons ( $\delta 193.1$ and 188.7) and two quaternary carbons with attachment of oxygen atoms ( $\delta 87.5$ and 82.1) were observed in addition to the signals described above. The ${ }^{1} \mathrm{H}-\mathrm{NMR}$ and ${ }^{13} \mathrm{C}-\mathrm{NMR}$ data of compound IV were consistent with those of stelleranol $[11,12]$. There were five chiral carbons including $\mathrm{C}-2, \mathrm{C}-3, \mathrm{C}-8, \mathrm{C}-2$ ", and $\mathrm{C}-3$ " in the structure of stelleranol (Figure 1). Among them, the absolute configurations at both $\mathrm{C}-2$ and $\mathrm{C}-3$ were determined to be $R$ according to comparison of the NMR data of stelleranol with the published data of (-)epicatechin [11,12]. The absolute configurations of another three carbons, namely $\mathrm{C}-8, \mathrm{C}-2$ " and $\mathrm{C}-3$ ", were determined by comparison of the $\mathrm{CD}$ spectrum of compound IV with those of genkwanol B (2) and genkwanol C (3) [13]. The CD spectrum of compound IV (Figure 2) was similar to that of genkwanol $C$, and opposite to that of genkwanol B. Therefore, the absolute configurations at $C-2, C-3, C-8, C-2$ " and C-3" positions of stelleranol were fully substantiated to be $R, R, R, R$ and $S$.

We also identified compounds I-III to be neochamaejasmin B (I), genkwanol B (II), genkwanol C (III) by comparing their spectra with the published data [13-15]. Compound I was a biflavonone whereas compounds IIIV were stereo isomers of spirobiflavonoids (Figure 1).

\section{Antiviral activity of the isolated compounds}

The in vitro antiviral activity of compounds I-IV against RSV was tested with CPE reduction assay and the MTT method. The SI value calculated from the ratio of $\mathrm{CC}_{50}$ to $\mathrm{IC}_{50}$ was used as an important parameter to evaluate the in vitro antiviral activity of the compounds. Compounds II, III and IV showed similar in vitro antiviral activity against RSV with $\mathrm{IC}_{50}$ values of 9.6, 6.6, $10.2 \mu \mathrm{M}$ and SI values of 11.0, 21.9, 15.8 respectively whereas compound I did not show anti-RSV effect in its maximal non-cytotoxic concentration (MNCC), the highest concentration tested in the CPE reduction assay (Table 1).

\section{Discussion}

Quite a few biflavonoids possess antiviral activities against a number of viruses such as RSV [4,16-20]. Biflavonoids isolated from Radix Wikstroemiae, e.g. (+)-nortrachelogenin, genkwanol A, wikstrol B and daphnodorin $B$, are moderately active against HIV-1 in vitro [4]. However, the anti-RSV activity of biflavonoids from W. indica has not been discussed before. Three spirobiflavonoids II, III and IV possess similar potent anti-RSV activity to the positive controlled drug ribavirin. In addition, stelleranol is a spirobiflavonoid consisted of five chiral carbons. The absolute configurations of the five chiral carbons in stelleranol are completely substantiated in this study, and the
CD spectrum of stelleranol has been given for the first time.

\section{Conclusion}

Neochamaejasmin B, genkwanol B, genkwanol C and stelleranol were isolated from Radix Wikstroemiae and the complete absolute configurations of five chiral carbons in stelleranol were substantiated for the first time. Furthermore, the anti-RSV activity of genkwanol B, genkwanol $\mathrm{C}$ and stelleranol was reported for the first time.

\section{Abbreviations}

CPE: cytopathic effect; ESI-MS: electrospray ionization-mass spectrometry HPLC: high performance liquid chromatography; HR-ESI-MS: high resolutionelectrospray ionization-mass spectrometry; MTT: 3-(4,5-dimethylthiazol-2-yl)2,5-diphenyltetrazolium bromide; NMR: nuclear magnetic resonance spectrometry; ${ }^{1} \mathrm{H}-\mathrm{MNR}$ : proton magnetic resonance spectrometry; ${ }^{13} \mathrm{C}-\mathrm{NMR}$ : carbon magnetic resonance spectrometry; RSV: respiratory syncytial virus; SI: selective index; TLC: thin layer chromatography; UV: ultraviolet; HIV: human immunodeficiency virus.

\section{Competing interests}

The authors declare that they have no competing interests.

\section{Authors' contributions}

WH performed the chemical isolation, antiviral tests and manuscript preparation. XZ assisted in chemical isolation and manuscript preparation. YW and HYC conducted the antiviral experiments. VECO designed the antiviral experiments and revised the manuscript. YL designed the study and revised the manuscript. WY designed the overall study. All authors read and approved the final version of the manuscript.

\section{Acknowledgements}

This work was partially supported by the Natural Science Foundation of Guangdong Province (06025165), the Ministry of Education Key Project, China (106155), the Team Project of Natural Science Foundation of Guangdong Province (8351063201000003), and the Joint Funds of National Science Foundation of China (U0632010)

\section{Author Details}

'Department of Biology, The Chinese University of Hong Kong, Shatin, Hong Kong SAR, China, ${ }^{2}$ Institute of Traditional Chinese Medicine and Natural Products, Jinan University, Guangzhou, 510632, China, ${ }^{3}$ Guangdong Province Key Laboratory of Pharmacodynamic Constituents of Traditional Chinese Medicine and New Drug Research, Jinan University, Guangzhou, 510632, China and ${ }^{4}$ Biomedicine Research and Development Center, Jinan University, Guangzhou, 510632, China

Received: 11 March 2010 Accepted: 21 June 2010 Published: 21 June 2010

\section{References}

1. A group of editors for Chinese Materia Medica: Liaogewang. In Chinese Materia Medica Shanghai: Shanghai Science and Technology Press; 1999:423-427

2. The Pharmacopoeia Committee of the Ministry of Public Health, China: Liaogewang tablet. In Pharmacopoeia of the People's Republic of China 1977 Beijing: People's Medical Publishing House; 1978:16-17.

3. Lee KH, Tagahara K, Suzuki H, Wu RY, Haruna M, Hall IH, Huang HC, Ito K, lida T, Lai JS: Antitumor agents. 49. Tricin, kaempferol-3-O-beta- $D$ glucopyranoside and (+)-nortrachelogenin, antileukemic principles from Wikstroemia indica. J Nat Prod 1981, 44:530-535.

4. Hu K, Kobayashi H, Dong A, Iwasaki S, Yao X: Antifungal, antimitotic and anti-HIV-1 agents from the roots of Wikstroemia indica. Planta Med 2000, 66:564-567.

5. Nunome S, Ishiyama A, Kobayashi M, Otoguro K, Kiyohara H, Yamada H, Omura S: In vitro antimalarial activity of biflavonoids from Wikstroemia indica. Planta Med 2004, 70:76-78. 
6. Wang $L Y$, Unehara $T$, Kitanaka S: Anti-inflammatory activity of new guaiane type sesquiterpene from Wikstroemia indica. Chem Pharm Bull (Tokyo) 2005, 53:137-139.

7. Kato A, Hashimoto Y, Kidokoro M: (+)-Nortrachelogenin, a new pharmacologically active lignan from Wikstroemia indica. J Nat Prod 1979, 42:159-162.

8. Wang LY, Unehara N, Kitanaka S: Lignans from the roots of Wikstroemia indica and their DPPH radical scavenging and nitric oxide inhibitory activities. Chem Pharm Bull (Tokyo) 2005, 53:1348-1351.

9. Ho WS, Xue JY, Sun SSM, Ooi VEC, Li YL: Antiviral activity of daphnoretin isolated from Wikstroemia indica. Phytother Res 2010, 24:657-661.

10. Li Y, But PPH, Ooi VEC: Antiviral activity and mode of action of caffeoylquinic acids from Schefflera heptaphylla (L.) Fordin. Antiviral Res 2005, 68:1-9.

11. Feng BM, Pei YH, Hua HM: A new biflavonoid from Stellera chamaejasme L. Chin Chem Lett 2004, 15:61-62.

12. Feng BM, Gong XJ, Shi LY, Jiang G, Pei YH, Huang YQ: Studies on phenolic compounds from Stellera chamaejasme. Zhongguo Zhong Yao Za Zhi 2008, 33:403-405.

13. Baba K, Taniguchi M, Kozawa M: A third spirobiflavonoid genkwanol C from Daphne genkwa. Phytochemistry 1993, 33:913-916.

14. Baba K, Taniguchi M, Kozawa M: A spirobiflavonoid genkwanol B from Dapnhe genkwa. Phytochemistry 1992, 31:975-980.

15. Niwa M, Tatmatsu H, Liu GQ: Isolation and structure of two C-3/C-3"biflavonids neochamaejasmenin A and neochamaejasmenin B. Chem Lett 1984, 148:539-542.

16. Lin YM, Anderson H, Flavin MT, Pai YHS: In vitro anti-HIV activity of biflavanoids isolated from Rhus succedanea and Garcinia multiflora. $J$ Nat Prod 1997, 60:884-888.

17. Miki K, Nagai T, Suzuki K, Tsujimura R, Koyama K, Kinoshita K, Furuhata K, Yamada $\mathrm{H}$, Takahashi $\mathrm{K}$ : Anti-influenza virus activity of biflavonoids. Bioorg Med Chem Lett 2007, 17:772-775.

18. Sanchez I, Gomez-Garibay F, Taboada J, Ruiz BH: Antiviral effect of flavonoids on the dengue virus. Phytother Res 2000, 14:89-92.

19. Lin YM, Flavin MT, Schure R, Chen FC, Sidwell R, Barnard DI, Huffman JH, Kern ER: Antiviral activities of biflavonoids. Planta Med 1999, 65:120-125.

20. Ma SC, But PPH, Ooi VEC, He YH, Lee SHS, Lee SF, Lin RC: Antiviral amentoflavone from Selaginella sinensis. Biol Pharm Bull 2001, 24:311-312

doi: $10.1186 / 1749-8546-5-23$

Cite this article as: Huang et al., Antiviral biflavonoids from Radix Wikstroemiae (Liaogewanggen) Chinese Medicine 2010, 5:23

Submit your next manuscript to BioMed Centra and take full advantage of:

- Convenient online submission

- Thorough peer review

- No space constraints or color figure charges

- Immediate publication on acceptance

- Inclusion in PubMed, CAS, Scopus and Google Scholar

- Research which is freely available for redistribution

Submit your manuscript at www.biomedcentral.com/submit
C Biomed Central 